\title{
Attachment of Human Endothelial Cells to Polyester Vascular Grafts: Pre-Coating With Adhesive Protein Assemblies and Resistance to Short-Term Shear Stress
}

\author{
J. CHLUPÁČ ${ }^{1,2}$, E. FILOVÁ ${ }^{1}$, T. RIEDEL ${ }^{3}$, M. HOUSKA ${ }^{3}$, E. BRYNDA ${ }^{3}$, \\ M. REMY-ZOLGHADRI ${ }^{4}$, R. BAREILLE ${ }^{4}$, P. FERNANDEZ $^{4}$, R. DACULSI $^{4}$, \\ C. BOURGET ${ }^{4}$, L. BORDENAVE ${ }^{4}$, L. BAČÁKOVÁ ${ }^{1}$
}

${ }^{1}$ Department of Biomaterials and Tissue Engineering, Institute of Physiology Academy of Sciences of the Czech Republic, Prague, Czech Republic, ${ }^{2}$ Department of Transplant Surgery, Institute for Clinical and Experimental Medicine, Prague, Czech Republic, ${ }^{3}$ Institute of Macromolecular Chemistry, Academy of Sciences of the Czech Republic, Prague, Czech Republic, ${ }^{4}$ Inserm U577, Université Victor Segalen, Bordeaux, France

Received May 26, 2013

Accepted September 27, 2013

On-line January 8, 2014

\section{Summary}

Cardiovascular prosthetic bypass grafts do not endothelialize spontaneously in humans, and so they pose a thrombotic risk. Seeding with cells improves their performance, particularly in small-caliber applications. Knitted tubular polyethyleneterephthalate (PET) vascular prostheses $(6 \mathrm{~mm})$ with commercial type I collagen (PET/Co) were modified in the lumen by the adsorption of laminin (LM), by coating with a fibrin network (Fb) or a combination of $\mathrm{Fb}$ and fibronectin ( $\mathrm{Fb} / \mathrm{FN}$ ). Primary human saphenous vein endothelial cells were seeded $\left(1.50 \times 10^{5} / \mathrm{cm}^{2}\right)$, cultured for $72 \mathrm{~h}$ and exposed to laminar shear stress $15 \mathrm{dyn} / \mathrm{cm}^{2}$ for 40 and $120 \mathrm{~min}$. The control static grafts were excluded from shearing. The cell adherence after $4 \mathrm{~h}$ on PET/Co, PET/Co +LM, $\mathrm{PET} / \mathrm{Co}+\mathrm{Fb}$ and $\mathrm{PET} / \mathrm{Co}+\mathrm{Fb} / \mathrm{FN}$ was $22 \%, 30 \%, 19 \%$ and $27 \%$ of seeding, respectively. Compared to the static grafts, the cell density on PET/Co and PET/Co +LM dropped to $61 \%$ and $50 \%$, respectively, after $120 \mathrm{~min}$ of flow. The cells on PET/Co $+\mathrm{Fb}$ and $\mathrm{PET} / \mathrm{Co}+\mathrm{Fb} / \mathrm{FN}$ did not show any detachment during $2 \mathrm{~h}$ of shear stress. Pre-coating the clinically-used PET/Co vascular prosthesis with $\mathrm{LM}$ or $\mathrm{Fb} / \mathrm{FN}$ adhesive protein assemblies promotes the adherence of endothelium. Cell retention under flow is improved particularly on fibrin-containing ( $\mathrm{Fb}$ and $\mathrm{Fb} / \mathrm{FN}$ ) surfaces.

\section{Key words}

Blood vessel prosthesis $\bullet$ Polyethylene terephthalate $\bullet$ Endothelial cells • Fibrin • Shear stress

\section{Corresponding author}

J. Chlupáč, Department of Biomaterials and Tissue Engineering, Institute of Physiology, v.v.i., Academy of Sciences of the Czech Republic, Videnska 1083, 14220 Prague 4-Krc, Czech Republic. E-mail: jarach@centrum.cz

\section{Introduction}

Atherosclerosis is one of the most common diseases in the developed countries. Surgical intervention in the form of a bypass or blood vessel substitution is often required to restore the blood supply to the diseased heart, brain, extremities or inner organs (Balaz et al. 2009). Autologous (patient's own) artery or vein is an ideal natural material for bypass graft procedures, but it is often unavailable or unsuitable for reconstruction (Matia et al. 2007, Kachlík et al. 2008). Vascular prostheses made of non-degradable synthetic polymers are therefore widely used in cardiovascular surgery, namely expanded polytetrafluoroethylene (ePTFE, Teflon, Gore-Tex) or polyethylene terephthalate (PET, Dacron). Although they perform well as substitutes for large-caliber blood 
vessels, they fail in small-caliber applications $(\leq 6 \mathrm{~mm})$, e.g. in coronary, below-the-knee or micro-vascular regions (Kannan et al. 2005, Chlupác et al. 2009, Rémy et al. 2013).

The healing process of synthetic vascular prostheses is incomplete in humans. It comprises the formation of a fibrous capsule around the outer surface, minimal capillary in-growth into the fiber interstices, and no lining or sparse lining with endothelial cells (EC) in the lumen (Pasquinelli et al. 1990). Thus, the bloodcontacting surface remains unhealed and covered with a layer of compacted plasma proteins only. Synthetic vascular grafts therefore fail, in part due to thrombosis resulting from the lack of endothelium (Zilla et al. 2007). Moreover, the mismatch in mechanical properties between the elastic native artery and the rigid prosthetic graft leads to proliferation (intimal hyperplasia - stenosis) of vascular smooth muscle cells (VSMC) which cannot be regulated by missing EC (Sarkar et al. 2006, Varga et al. 2013). Bio-functionalization of vascular prostheses and subsequent in vitro lining with EC was previously shown to reduce the risk of thrombosis and graft failure and to improve the clinical performance of vascular prostheses (Vara et al. 2005, Bordenave et al. 2008, Deutsch et al. 2009).

There is no significant difference in long-term patency between PET and ePTFE bypass grafts (Roll et al. 2008), and the choice between PET and ePTFE is usually left to the discretion of the implanting surgeon; however, some vascular specialists prefer PET over ePTFE because PET has better handling characteristics, and there is less bleeding from suture holes and a lower tendency to form peri-graft seroma (Jonas et al. 1987).

The objectives of our study were to modify the inner surface of clinically-used collagen type Iimpregnated PET vascular prostheses with immobilization of the extracellular matrix (ECM) protein laminin (LM), coating them with a network of blood coagulation protein fibrin $(\mathrm{Fb})$ or coating them with assemblies of fibrin and fibronectin ( $\mathrm{Fb} / \mathrm{FN})$. In addition, we aimed to seed primary human patient-derived EC in the lumen of the grafts to approximate the synthetic prosthesis to the natural vessel. Initial adherence and subsequent retention of the cells under flow conditions up to 2 hours (h) representing a clinical small-diameter bypass graft were evaluated in a bioreactor with a view to tissue engineering of less thrombogenic bio-artificial vascular grafts.

\section{Methods}

Knitted crimped tubular PET vascular prostheses with bovine type I collagen impregnation were received from the manufacturer (6 mm inner diameter, courtesy of VÚP Joint-Stock Comp., Brno, Czech Republic) (Fig. 1).
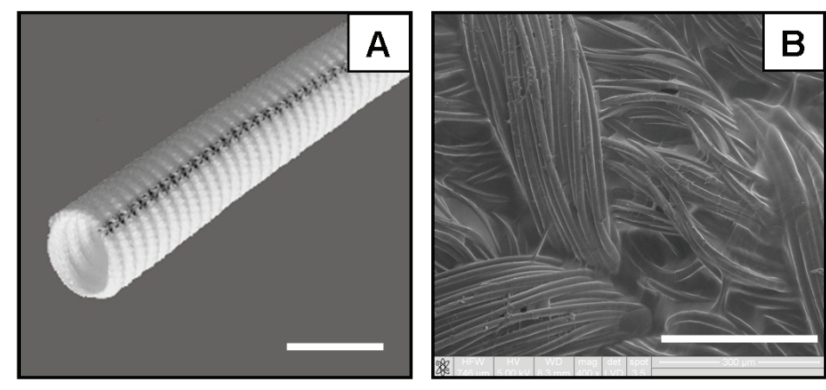

Fig. 1. A. Knitted crimped polyethylene-terephthalate (PET) vascular prostheses $(6 \mathrm{~mm})$ with commercial bovine type I collagen impregnation (VúP Joint-Stock Comp., Brno, Czech Republic), bar $=1 \mathrm{~cm}$. B. Ultrastructure of the textile knitted fashion of the prosthesis, scanning electron microscopy (NOVA nanoSEM 200, FEI, USA), magnification $400 \times$ and bar $=300 \mu \mathrm{m}$.

The prostheses were cut into pieces $20 \mathrm{~cm}$ in length and modified on the inner surface by immobilization of LM (Engelbreth-Holm-Swarm Murine sarcoma, Sigma) $40 \mu \mathrm{g} / \mathrm{ml}$ in phosphate-buffered saline (PBS) overnight or by a Fb network coating prepared by activation of human fibrinogen (Fbg) (Sigma) with surface-attached thrombin (Sigma) according to a previously-published method (Riedel et al. 2009). Briefly, Fbg (50 $\mu \mathrm{g} / \mathrm{ml}$ in Tris buffer (TB) for $60 \mathrm{~min}$ ) was adsorbed on the surface of the graft, rinsed with TB, followed by thrombin (2.5 NIH U/ml in TB for $10 \mathrm{~min}$ ), $\mathrm{TB}$, and $\mathrm{Fbg}(200 \mu \mathrm{g} / \mathrm{ml}$ in TB containing antithrombin III (Chromogenix) $(0.5 \mathrm{U} / \mathrm{ml})$ for $2 \mathrm{~h}$. A surface fibrin network was formed by catalytic action of the surfaceattached thrombin on the ambient fibrinogen solution. In the third sample, the fibrin network was further coated with FN (human plasma, Roche) $50 \mu \mathrm{g} / \mathrm{ml}$ in PBS overnight. An unmodified (commercial) PET/Co prosthesis served as a control graft. Thus, 4 graft types were prepared: $\mathrm{PET} / \mathrm{Co}$, $\mathrm{PET} / \mathrm{Co}+\mathrm{LM}, \mathrm{PET} / \mathrm{Co}+\mathrm{Fb}$ and $\mathrm{PET} / \mathrm{Co}+\mathrm{Fb} / \mathrm{FN}$ (Institute of Macromolecular Chemistry, Academy of Sciences of the Czech Republic, v.v.i.). They were all immersed for $12 \mathrm{~h}$ into M199 standard culture medium (Invitrogen).

Human saphenous vein endothelial cells (HSVEC) were enzymatically harvested from vein remnants (according to Fernandez et al. 2001) obtained from patients undergoing cardiac bypass surgery 
(Université Victor Segalen, Bordeaux, France), cultured in polystyrene flasks (Falcon, $75 \mathrm{~cm}^{2}$ ) and amplified to passage number P3-5. The procedure was approved by the local Ethics Committee. The culture medium consisted of M199, $20 \%$ of fetal calf serum (FCS) (PAA), heparin $50 \mathrm{IU} / \mathrm{ml}$ (Choay), basic fibroblast growth factor b-FGF $10 \mathrm{ng} / \mathrm{ml}$ (Promocell) and a mixture solution of penicillin $\left(10 \times 10^{3} \mathrm{IU} / \mathrm{ml}\right)$, streptomycin $(10 \mu \mathrm{g} / \mathrm{ml})$ (Sigma) and amphotericin B $(250 \mu \mathrm{g} / \mathrm{ml})$ (Invitrogen). The cellular suspension was homogenized in a fresh medium and injected into the lumen of the prosthesis. Both ends were ligatured and the grafts were placed into a rotating device (Endostrabilisator, Biegler Co. Ltd., Austria) for $4 \mathrm{~h}$ (at $5 \mathrm{rpm}$ ) to achieve homogeneous cell seeding. The initial seeding density was about $1.50 \times 10^{5}$ cells $/ \mathrm{cm}^{2}$. The seeding was followed by 3 days of maturation in culture flasks with a fresh complete medium without rotation in a humid incubator at $37^{\circ} \mathrm{C}$ with $5 \% \mathrm{CO}_{2}$.

The flow experiment was performed in a custombuilt hemodynamic chamber (Inserm U577, Université Victor Segalen, Bordeaux, France) (Fig. 2) consisting of a silicon tubing circuit (Tygon, Masterflex), a peristaltic pump (Cobe, Stöckert, Germany), a water container with a heater (Julabo, Labortechnik Ltd., Germany), a flowmeter (EMKA Technologies, Transsonic Systems Inc., USA), and a tensiometer (Sirecust 960, Siemens).

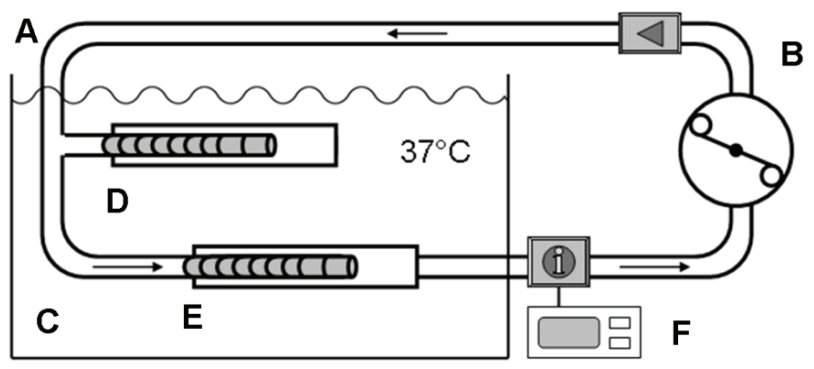

Fig. 2. Hemodynamic bioreactor consisting of a circuit of silicon tubing (A), a peristaltic pump (B), a water container with a heater (C), a static control prosthesis that is located in a blind branch (D), a dynamic tested prosthesis that is exposed to flow (E) and a flow-meter (F) (Inserm U577, Université Victor Segalen, Bordeaux, France).

The prosthesis was mounted on a special metal connector creating laminar flow, and the dynamic conditions inside the bioreactor simulated human arterial circulation for 40 and $120 \mathrm{~min}$ (temperature $37^{\circ} \mathrm{C}$, flow $500 \mathrm{ml} / \mathrm{min}$, pulsatile pressure $120 / 60 \mathrm{~mm} \mathrm{Hg}$, laminar shear stress (SS) 15 dynes $/ \mathrm{cm}^{2}$ and medium viscosity 0.04 Poiseuille - achieved by adding $8 \%$ Dextran
(Sigma, D4751, MW 68 800). FCS (10\%) was added to the medium in the 120-min experiment. A static control prosthesis was placed into a blind branch of the circuit (Fig. 2D) and was thus submitted to the same conditions of medium pressure and temperature but excluding flow and shear stress.

After each step of the experiment (seeding maturation - flow) a prosthesis ring of defined surface area was cut open, washed with PBS and stained with the immunofluorescent Live/Dead (L/D) Viability/Cytotoxicity Kit (Molecular Probes) to visualize the homogeneity and the efficiency of the cell adhesion and retention (Olympus IX50 fluorescence microscope and Olympus DP70 digital camera, magnification $10 \times$ ). The cells were then removed from the support using a PBS solution with $0.125 \%$ trypsin (Sigma) and $0.0625 \%$ EDTA (T/E, Sigma). M199 medium with $10 \%$ FCS was used to stop the action of the T/E solution. After centrifugation ( $5 \mathrm{~min}, 300 \mathrm{~g}$ ) and resuspension, the cells were counted in a $1 \mathrm{~mm}^{3}$ Malassez chamber ( 8 counts) to obtain the cell number and to calculate the cell population density. The surface of the prosthesis was observed again in the fluorescence microscope to check that it was really devoid of cells after trypsinization. The cell densities on the flow-exposed prostheses were compared to the corresponding static grafts to evaluate the cell detachment during flow. Pieces of the seeded prostheses were also stained with mouse anti-human- $\beta$-actin IgG1 (1:100) monoclonal antibody (Sigma) or rabbit anti-human-von Willebrand Factor IgG (1:100) monoclonal antibody (Sigma), and the cell nuclei were counterstained with propidium iodide $(5 \mu \mathrm{g} / \mathrm{ml})$ (Sigma). The morphology of the cells was then evaluated with confocal microscopy (Leica TCS SP2 AOBS) at magnification $10 \times$.

\section{Statistical analysis}

The data is expressed as mean and standard deviation (SD) from 4 to 16 counts. The experiments on $\mathrm{PET} / \mathrm{Co}$ and $\mathrm{PET} / \mathrm{Co}+\mathrm{Fb}$ (40 min) were run in duplicate and the data was pooled. One-way ANOVA multivariate analysis (Student-Newman-Keuls test) was applied for a statistical evaluation (SigmaStat 3.1 2004, Systat Software, Inc.). Statistical significance was considered when the probability of error was $p \leq 0.05$.

\section{Results}

The adherence of HSVEC to the PET vascular prostheses is shown in Figure 3A. The cell densities $4 \mathrm{~h}$ 
after rotational seeding amounted to $22 \%$ of the initial seeding density on PET/Co, $30 \%$ of the initial seeding density on PET/Co +LM, a value of $19 \%$ on PET/Co $+\mathrm{Fb}$, and a value of $27 \%$ on PET/Co $+\mathrm{Fb} / \mathrm{FN}$. Thus, the cell adhesion and seeding efficiency was better on the vascular prostheses coated with LM $(\mathrm{p}<0.001)$ and $\mathrm{Fb} / \mathrm{FN}$ $(p<0.05)$ than on the control PET/Co prosthesis. Further differences were detected among the coated grafts coating with LM resulted in significantly better adhesion than coating with $\mathrm{Fb}(\mathrm{p}<0.001)$ or with $\mathrm{Fb} / \mathrm{FN}(\mathrm{p}<0.05)$. Deposition of $\mathrm{Fb}$ resulted in cell density similar to the control graft, but adding $\mathrm{FN}$ to the $\mathrm{Fb}$ gel (PET/Co $+\mathrm{Fb} / \mathrm{FN})$ enhanced the cell adherence $(\mathrm{p}<0.01)$.
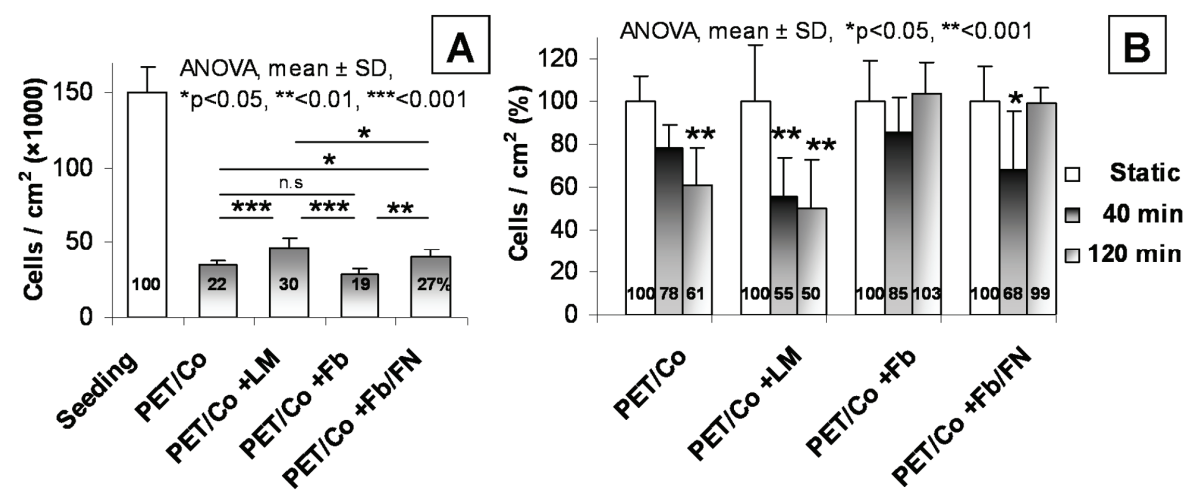

Fig. 3. A. Adherence of human saphenous vein endothelial cells to PET vascular prostheses $4 \mathrm{~h}$ after seeding $1.50 \times 10^{5} \mathrm{cells} / \mathrm{cm}^{2}$. The percentage of initial seeding density is shown at the bottom of each column.

B. Flow-resistance of human saphenous vein endothelial cells on PET vascular prostheses. The laminar shear stress was $15 \mathrm{dyn} / \mathrm{cm}^{2}$. The statistical differences are given versus the corresponding static control $(=100 \%)$, which was left without shearing (white columns). Data are presented as mean \pm standard deviation (SD), number of measurements $n=4-16$. The experiments on PET/Co and PET/Co +Fb (40 min) were run in duplicate. Polyethylene terephthalate (PET), collagen type I impregnation (Co), laminin (LM), fibrin gel (Fb), fibronectin (FN), standard deviation (SD), non-significant (n.s.).

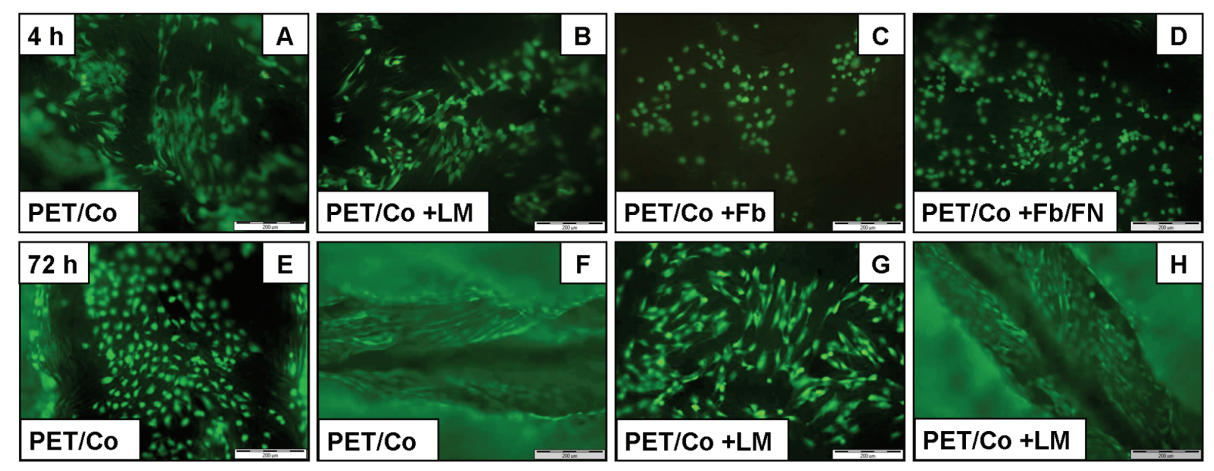

$\mathrm{PET} / \mathrm{CO}$
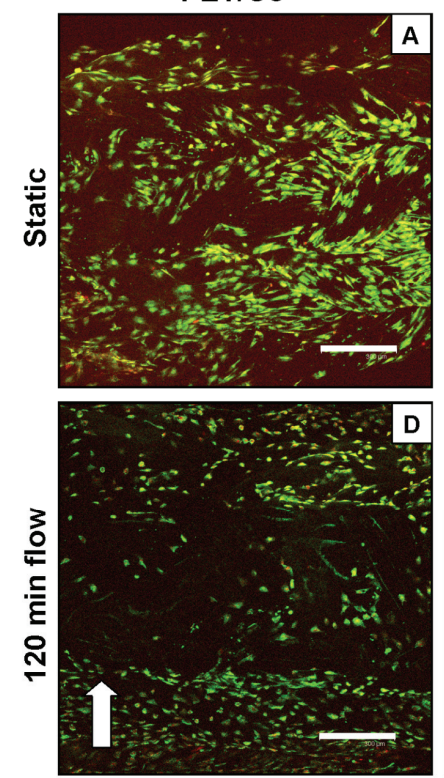

PET/Co + LM
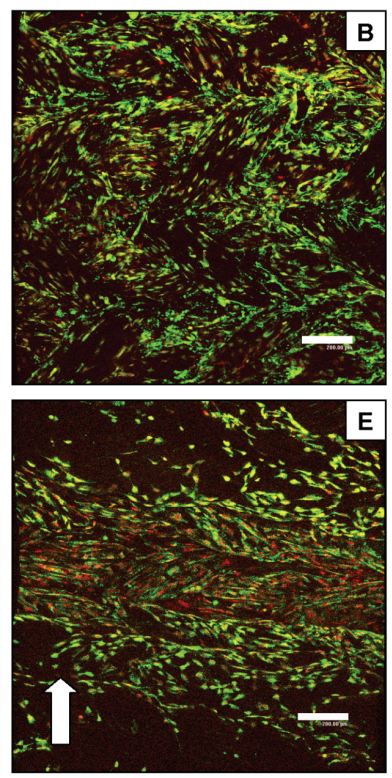

$\mathrm{PET} / \mathrm{Co}+\mathrm{Fb}$

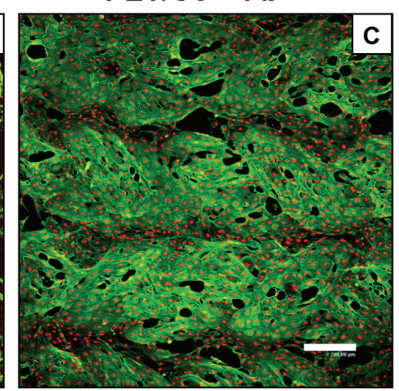

Fig. 4. Morphology of adhering human saphenous vein endothelial cells on PET vascular prostheses $4 \mathrm{~h}$ after seeding $1.50 \times 10^{5}$ cells $/ \mathrm{cm}^{2}$ (A-D) and $72 \mathrm{~h}$ after seeding (E-H). Staining with the Live/Dead Viability/Cytotoxicity Kit (Molecular probes), viable cells are in green. Olympus IX50 fluorescence microscope, Olympus DP70 digital camera, magnification $10 \times$, scale bar $200 \mu \mathrm{m}$. Polyethylene terephthalate (PET), collagen type I impregnation (Co), laminin (LM), fibrin gel $(\mathrm{Fb})$, fibronectin (FN).

Fig. 5. Morphology of human saphenous vein endothelial cells on PET/Co (A and D), PET/Co + LM (B and $\mathbf{E}$ ) and $\mathrm{PET} / \mathrm{Co}+\mathrm{Fb}$ (C and $\mathbf{F}$ ) vascular prostheses $72 \mathrm{~h}$ after seeding in static conditions (A-C) and after subsequent application of $120 \mathrm{~min}$ of flow (D-F). The flow direction is indicated by the arrow (D-F). Immunofluorescence of $\beta$-actin (green) ( $A$ and C, D-F) and of von Willebrand factor (green) (B) with cell nuclei counterstained with propidium iodide (red) (A-F). Leica TCS SP2 AOBS confocal microscope, magnification $10 \times$, zoom $2 \times$, scale bar $300 \mu \mathrm{m}$ (A and D), magnification $10 \times$, scale bar $200 \mu \mathrm{m}$ (B and C, E and F). Polyethylene terephthalate (PET), collagen type I impregnation (Co), laminin (LM), fibrin gel (Fb). 
The morphology of the HSVEC is presented in Figure 4. Viable cells are green, dead cells would be visible in red. However, there are no dead cells on any of the grafts. The adhering cells are becoming spread on PET/Co and PET/Co +LM (Fig. 4A,B); however, they are slightly less numerous and still round in shape on $\mathrm{PET} / \mathrm{Co}+\mathrm{Fb}$ and PET/Co +Fb/FN (Fig. 4C,D). After $72 \mathrm{~h}$ of growth - before they are submitted to the shear stress the EC form a confluent monolayer, which seems to be more compact in the valleys (Fig. 4F,H) than on the crests (Fig. 4E,G) of the crimped (i.e. waved structure) prosthesis.

The population densities of the HSVEC after exposure to the flow conditions in a bioreactor are given in Figure 3B. They are compared in relative numbers to the static control prosthesis $(=100 \%)$. The cell densities on PET/Co dropped to $78 \%$ (n.s.) after 40 min of shear stress and to $61 \%(\mathrm{p}<0.001)$ after $120 \mathrm{~min}$ of shear stress, suggesting significant cell loss under flow of $2 \mathrm{~h}$. The significant decrease in cell numbers was even more evident on the PET/Co +LM prostheses (55\%, p $<0.001$ and $50 \%, \mathrm{p}<0.001)$. However, no cell denudation was noted on the $\mathrm{PET} / \mathrm{Co}+\mathrm{Fb}$ vascular prostheses after both $40 \mathrm{~min}$ and $120 \mathrm{~min}$ of flow. Similarly, no cell loss was observed on $\mathrm{PET} / \mathrm{Co}+\mathrm{Fb} / \mathrm{FN}$ during $120 \mathrm{~min}$ of shear stress application, though a significant decrease in cell density was noted after $40 \min (68 \%, \mathrm{p}<0.05)$.

The morphology of the HSVEC on PET/Co, $\mathrm{PET} / \mathrm{Co}+\mathrm{LM}$ and in $\mathrm{PET} / \mathrm{Co}+\mathrm{Fb}$ in static conditions and after subsequent application of flow in dynamic conditions, as seen by confocal microscopy, is shown in Figure 5. The EC form a confluent monolayer after $72 \mathrm{~h}$ of static growth (Fig. 5A-C) and they become subconfluent due to certain cell denudation after delivery of 120-min-shear stress on PET/Co and on PET/Co +LM (Fig. 5D and E). However, the EC maintained their endothelial phenotype, as shown by immunofluorescence of the cytoskeletal $\beta$-actin (Fig. 5A and C,D-F) and of von Willebrand factor, which is stored in the secretion granulae (Weibel-Palade bodies) in the cytoplasm of EC (Fig. 5B). Cell detachment on the crimped prosthesis occurred mainly in the regions of the crests (middle third of Fig. 5D and the upper and lower third of Fig. 5E), whereas the cells in the valleys remained attached (upper and lower third of Fig. 5D and middle third of Fig. 5E). No flow-dependent cell loss was observed when EC were seeded on PET/Co +Fb (Fig. 5F). In our study, we did not observe cell alignment with the direction of flow, since this physiological phenomenon occurs after longer application of shear stress, usually after 6-24 h (Punchard et al. 2007).

\section{Discussion}

Endothelial cell seeding on vascular implants was introduced in the $1980 \mathrm{~s}$, and it was proved to reduce the thrombogenicity of implanted prosthetic grafts (Ortenwall et al. 1990) and to enhance their patency (Meinhart et al. 2001). Impregnation of textile vascular prostheses with a collagen sealant was proposed in 1960 in order to make the graft impermeable to blood at the time of implantation; however, impregnated prostheses are not optimal substrata for direct endothelialization (Chakfé et al. 1999). To establish a cell monolayer on graft surfaces, optimal attachment and spreading of the cells is desired, together with the ability to withstand shear stress. Several research groups therefore investigated pre-coating vascular prostheses with celladhesive substrates and exposing the seeded cells to flow conditions (Rémy-Zolghadri et al. 2004, Bacakova et al. 2011).

EC seeding of rough-surfaced vascular prostheses with a tissue culture technique is problematic. Many authors have demonstrated the importance of providing a protein matrix to facilitate the adhesion, growth and retention of EC on prosthetic graft surfaces. Sentissi et al. (1986) cultured bovine aortic EC on ePTFE grafts pretreated with type I collagen and fibronectin. Cell detachment amounted to 7-11\% after 1-hour of flow (Sentissi et al. 1986).

Gourevitch et al. (1988) seeded HSVEC and human omental EC on PET grafts treated with various protein coatings. The 100-min adhesion was as high as $86 \%$ on human cold insoluble globulin and $82 \%$ on $1 \%$ gelatin-coated grafts, and as low as $58 \%$ on alginatetreated PET and $48 \%$ on untreated PET. Compared to the initial cell density, they also reported EC retention of $73 \%$ after $102 \mathrm{~min}$ of flow in an in vitro circuit on $6 \mathrm{~mm}$ gelatin-coated Dacron tubular grafts when perfused with a culture medium, and $64 \%$ when perfused with heparinized human blood. This cell retention, however, was achieved after $30 \mathrm{~min}$ of maturation only (Gourevitch et al. 1988). Although the seeding efficacy in our study was much lower (Fig. 3A), the flow-dependent retention (40 and $120 \mathrm{~min}$ ) of $\mathrm{EC}$ on our commercial PET/Co was comparable (78\% after $40 \mathrm{~min}$ and $61 \%$ after $120 \mathrm{~min}$ ) with gelatin-coated Dacron grafts.

The advantage of providing a protein adhesive 
substrate to facilitate the endothelialization of vascular grafts was also demonstrated in vivo. Coating ePTFE grafts with fibronectin (FN) improved cell in-growth and surface endothelialization in a porcine interposition graft model; however, additional seeding of the FN-coated grafts with autologous EC (harvested from jugular vein) resulted in the most rapid EC coverage and excellent graft patency (Seeger and Klingman 1988).

Vohra et al. (1992) coated FN on ePTFE and gelatin on Dacron grafts. After seeding HSVEC $(1.40 \times$ $10^{5} / \mathrm{cm}^{2}$ ) on both coated samples they reached $60 \%$ seeding efficiency on ePTFE and $75 \%$ seeding efficiency on Dacron, at 90 min after seeding (Vohra et al. 1992). The cell retention after 120 min of shear stress (1.7 and $2.6 \mathrm{dyn} / \mathrm{cm}^{2}$ ) was $55 \%$ and $57 \%$ on FN-coated ePTFE and $69 \%$ and $67 \%$ on gelatin-impregnated Dacron grafts, respectively. In our study, the seeding density was similar $\left(1.50 \times 10^{5} \mathrm{HSVEC} / \mathrm{cm}^{2}\right)$, but the seeding efficiency amounted to $22 \%$ only on PET/Co after $4 \mathrm{~h}$ of culture. Under 40-min flow and 120-min flow, the resulting cell retention was again comparable $78 \%$ on FN-coated ePTFE grafts and $61 \%$ on gelatinimpregnated Dacron grafts.

Pronk et al. (1994) investigated human peritoneal mesothelial cells (HMC) as an alternative source to EC for seeding Dacron vascular grafts. They found that the behavior of HMC was similar to that of human umbilical vein EC (HUVEC), and they reported $35 \%$ seeding efficiency after $60 \mathrm{~min}\left(2.50 \times 10^{5}\right.$ $\mathrm{HMC} / \mathrm{cm}^{2}$ ) on plain Dacron and about $10 \%$ more on FN-coated $(10 \mu \mathrm{g} / \mathrm{ml})$ Dacron. Interestingly, a positive effect of FN pre-coating on cell adherence to the prosthesis was evident when the cells were seeded both in a serum-free medium ( $\mathrm{p}=0.066$, n.s.) and in a serumcontaining medium $(\mathrm{p}=0.046, \mathrm{~s}).(10 \% \mathrm{FCS})$ (Pronk et al. 1994). By analogy with this, we found $22 \%$ seeding efficiency of HSVEC on plain PET/Co, and this was further increased by surface pre-coating with LM up to $30 \%$ and with $\mathrm{Fb} / \mathrm{FN}$ up to $27 \%$. The slight discrepancy can be explained by the different cell type and by the lower seeding density in our study $\left(1.50 \times 10^{5}\right.$ HSVEC $/ \mathrm{cm}^{2}$ ). Similarly, we also seeded cells in a serumcontaining medium (20\% FCS).

However, Tunstall et al. (1995) found no enhanced adhesion of HUVEC $\left(5.0 \times 10^{4} / 0.3 \mathrm{~cm}^{2}\right)$ to Dacron prosthetic material pre-coated with $1 \%$ gelatin, with FN $(15 \mu \mathrm{g} / \mathrm{ml})$ or with LM $(6 \mu \mathrm{g} / \mathrm{ml})$ compared to bare Dacron pre-incubated with the complete (i.e. $10 \%$ human serum-containing) medium. The authors reported the adherence of $50-70 \%$ of cells $2 \mathrm{~h}$ after seeding on 5 types of complete medium-pre-incubated Dacron grafts with different porosity (Tunstall et al. 1995). In our study, the variations found in cell adhesion to different substrata on $\mathrm{PET} / \mathrm{Co}$ were statistically significant (Fig. 3A), and we also revealed differences by further testing the cell retention under flow conditions (Fig. 3B).

Sreerekha and Krishnan (2006) cultured ovine blood endothelial progenitor cells (EPC, $5.0 \times 10^{4} / \mathrm{cm}^{2}$ ) on Dacron graft patches pre-coated with fibrin composite matrix (Fb, FN, gelatin, factor XIII and vascular endothelial growth factor - VEGF). They reported 2-hour adherence of $60 \%, 70 \%$ and $80 \%$ on bare Dacron, low-density $\mathrm{Fb} \quad(2 \mathrm{mg} / \mathrm{ml})$ and high-density $\mathrm{Fb}$ $(10 \mathrm{mg} / \mathrm{ml})$-coated Dacron, respectively. Moreover, $\mathrm{Fb}$ induced differentiation of EPC into EC, as shown by staining of von-Willebrand factor, uptake of acetylated low-density lipoproteins (LDL) and nitric oxide (NO) synthesis. The cell proliferation over a period of $72 \mathrm{~h}$ and the NO production was also highest on high-density- $\mathrm{Fb}$ Dacron when compared to Fb-coated ePTFE. Applying shear stress $\left(20 \mathrm{dyn} / \mathrm{cm}^{2}\right)$ for $1 \mathrm{~h}$ resulted in no cell loss, and the NO production under dynamic conditions was again highest on high-density Fb-coated Dacron (Sreerekha and Krishnan 2006). In our study, the 4-hour adherence of HSVEC was only $22 \%$ on PET/Co, $19 \%$ on $\mathrm{PET} / \mathrm{Co}+\mathrm{Fb}$, and $27 \%$ on $\mathrm{PET} / \mathrm{Co}+\mathrm{Fb} / \mathrm{FN}$. This discrepancy may be due to the different prosthesis manufacturer and the use of a different cell type. Nevertheless, no cell loss during 2-hour flow on PET/Co $+\mathrm{Fb}$ and $\mathrm{PET} / \mathrm{Co}+\mathrm{Fb} / \mathrm{FN}$ in our experiment with tubular grafts is consistent with Sreerekha and Krishnan's study, confirming the concept that attached cells withstand the flow forces better on composite matrices resembling the natural ECM than on mono-protein layers.

The interaction of HUVEC with patches of commercial woven PET vascular prosthesis was extensively studied by Feugier et al. (2005). The cell adherence on plain grafts after 6-day culture was only $35 \%$ of the seeding density $\left(1.05 \times 10^{5} / \mathrm{cm}^{2}\right)$; however, the adhesion increased to $83 \%$ when the graft surface was experimentally bio-functionalized with a type I/III collagen coating. The cell retention under the action of 60-min shear stress of 10 and $20 \mathrm{dyn} / \mathrm{cm}^{2}$, in turn, amounted to $66 \%$ and $49 \%$, respectively. Although they reported enhanced cell spreading under flow, the cell loss was still considerable on all of the grafts (Feugier et al. 2005). We studied HSVEC $\left(1.50 \times 10^{5} / \mathrm{cm}^{2}\right)$ on knitted PET with commercial type I collagen impregnation, and 
this data is in full accordance with our results $-78 \%$ of HSVEC retained after $40-\mathrm{min} \mathrm{SS}$, and $61 \%$ retained after 120 -min SS (12 dyn $\left./ \mathrm{cm}^{2}\right)$. Interestingly, the number of cells in the study by Feugier et al. (2005) that remained adherent after shear stress was significantly higher on the smoother surface of ePTFE grafts than on the more irregularly shaped surface of the woven PET. The authors explain that EC adhered to the PET fibers in a more elongated fashion than to ePTFE, thus forming subconfluence, and that this may have caused the difference. Moreover, local irregularities of PET may give rise to local variations of shear stress and flow disturbances.

Wong et al. (2006) seeded ovine carotid artery EC $\left(4.00 \times 10^{5} / \mathrm{cm}^{2}\right)$ on commercial knitted PET graft patches, and achieved coverage of about $30 \%$ after 3 -day culture and $56 \%$ after 7-day culture. Cell retention under flow conditions decreased with increasing shearing and time of exposure values $-67 \%$ after $\mathrm{SS}=0.018 \mathrm{~N} / \mathrm{m}^{2}$ (15 $\mathrm{min}$ ) and $45 \%$ after $\mathrm{SS}=0.037 \mathrm{~N} / \mathrm{m}^{2}$ (60 $\mathrm{min}$ ) (Wong et al. 2006). In this experiment, both cell colonization in a static culture and cell resistance to flow were significantly better on PET grafts than on ePTFE grafts, in contrast to the findings of Feugier et al. (2005). Again, these results are comparable to our study with HSVEC on commercial knitted PET grafts.

Bérard et al. (2009) seeded human umbilical cord blood progenitor-derived EC (PDEC) on a commercial knitted PET prosthesis impregnated with bovine type I and III collagen in serum-free conditions. They found cell adherence of $20 \%$ at $1 \mathrm{~h}, 21 \%$ at $3 \mathrm{~h}$, and $29 \%$ (rounded values) at $24 \mathrm{~h}$ after seeding $2.00 \times$ $10^{5} \mathrm{PDEC} / \mathrm{cm}^{2}$ on planar graft patches. Although the cells did not proliferate significantly until day 9 in static conditions, the application of flow for $6 \mathrm{~h}$ (after 3 static days) restored the endothelial monolayer in tubular grafts (Bérard et al. 2009). In our study, we seeded $1.50 \times 10^{5}$ HSVEC $/ \mathrm{cm}^{2}$ with very similar cell adhesion of $22 \%$ after $4 \mathrm{~h}$. The flow experiment with tubular grafts was performed in the same bioreactor (Fig. 2.) with very similar dynamic conditions $(6 \mathrm{~mm}$ prosthesis, $15 \mathrm{dyn} / \mathrm{cm}^{2}$ ). By contrast, we observed significant cell denudation on the bare commercial PET/Co after $120 \mathrm{~min}$ of flow delivery. However, no cell loss was seen at 120 min when the cells were plated on PET/Co pretreated with either $\mathrm{Fb}$ or $\mathrm{Fb} / \mathrm{FN}$.

In our experiments, we chose crimped polyester vascular grafts (i.e. a wavy structure). These grafts have the clinical advantage of possible elongation (e.g. when the graft runs over a joint) and better resistance to bending (Hajjaji et al. 2012). The direction of the blood flow is perpendicular to the direction of crimping (Fig. 5D-F), and it runs over crests and valleys about $1 \mathrm{~mm}$ in length (Fig. 1A). Crimped vascular grafts are usually implanted with a certain degree of tension in an elongated fashion between the two sites of anastomoses to the native artery, thus partially removing the effect of crimping. However, in our study, the investigated prosthesis was mounted to a connector on one side only, thus retaining the crimped structure. The flow pattern had previously been investigated in a model of the crimped vascular grafts used in our study. Although a certain backflow was observed in the crimped tubes, no significant impact of crimping was found on the laminar flow pattern (Konfršt et al. 1994, 2005, Abdessalem et al. 1999). Moreover, no clinical difference between crimped and non-crimped grafts was found in terms of autologous cell seeding in a dog model (Baitella-Eberle et al. 1991). Interestingly, the HSVEC in our in vitro study were shed during flow more on the crests than in the valleys of the crimped grafts; however, this happened mainly on PET/Co and PET/Co +LM (Fig. 5D and E) - these are the grafts that sustained major cell detachment during flow.

To summarize current knowledge, it is evident that human EC of various origins can colonize commercial PET vascular grafts in vitro. However, substantial cellular detachment still occurs even after short-time action of flow conditions that represent the clinical situation. The contribution of our experiment consists in confirming these observations in clinicallyused tubular 3D bypass grafts submitted to flow in a hemodynamic chamber.

Laminin coating has previously been shown to increase both cell attachment and cell retention, but no difference from other ECM molecules was demonstrated (Salacinski et al. 2001). Surface modification using LM was reported to accelerate endothelialization of porous vascular grafts in rats (Williams et al. 2011). However, all these tests were carried out on PTFE. The seeding efficiency of HSVEC on PET/Co +LM in our study was the highest $-30 \%$ of seeding density; however, the cell numbers significantly dropped to $55 \%$ after $40 \mathrm{~min}$ of flow, and to $50 \%$ after $120 \mathrm{~min}$ of flow, compared to static conditions.

When the PET/Co prostheses in our study were coated with $\mathrm{Fb}$ or $\mathrm{Fb} / \mathrm{FN}$ assemblies, there was much better cell retention during the flow experiment, and no significant cell denudation was noted under shear stress up to $2 \mathrm{~h}$ (Fig. 5F). The EC adhere to collagen through 
integrin receptors $\alpha_{1} \beta_{1}$ and $\alpha_{2} \beta_{1}$, and to laminin through $\alpha_{3} \beta_{1}, \alpha_{6} \beta_{1}$ and $\alpha_{6} \beta_{4}$. Binding of fibronectin requires $\alpha v \beta_{1}$, $\alpha v \beta_{3}$ and $\alpha_{5} \beta_{1}$, and binding of fibrin also requires $\alpha v \beta_{3}$ and $\alpha_{5} \beta_{1}$ (Hynes et al. 2007, Takada et al. 2007). Integrin receptors $\alpha v \beta_{3}$ and $\alpha_{5} \beta_{1}$ play a crucial role in the adaptation of EC to hemodynamic force in terms of integrin activation, intracellular signaling and change in gene expression (Jalali et al. 2001). The fact that these integrins do not interact either with Co or with LM can explain the delamination of EC on PET/Co and PET/Co + LM under flow in this study. However, better cell coverage was observed on PET/Co $+\mathrm{Fb}$ and $\mathrm{PET} / \mathrm{Co}$ $+\mathrm{Fb} / \mathrm{FN}$. Thus lining the vascular prosthesis with $\mathrm{Fb}$ or $\mathrm{Fb} / \mathrm{FN}$ can provide the seeded EC with more matrixspecific signals (mediated by integrins $\beta_{1}$ and $\beta_{3}$ ) (Katsumi et al. 2004) that elicit desired cellular responses under shear stress.

The advantages of using fibrin as a substrate for cell seeding are that it can be isolated from autologous blood, it contains recognition sites for growth factors and cell adhesion receptors, and it induces matrix synthesis and differentiation of EC (Filová et al. 2009, Riedel et al. 2009). Moreover, a combination of fibrin gel with additional ECM components (e.g. FN) preserves EC adhesion and proliferation, and enables the formation of more mature contacts of focal adhesion (Filová et al. 2014). This was demonstrated by the higher cell density on PET/Co $+\mathrm{Fb} / \mathrm{FN}$ than on PET/Co +Fb (Fig. 3A).

Kjaergard and Weis-Fogh (1994) described a technique for sealing a high-porosity polyester prosthesis with autologous fibrin obtained from patients' own blood. The grafts could withstand pressure of $300 \mathrm{~mm} \mathrm{Hg}$, possessed good handling characteristics, and had no risk of any disease transmission (Kjaergard and Weis-Fogh 1994). Similarly, the commercial sealant of knitted PET vascular prostheses was experimentally replaced by autologous fibrin matrix, and these grafts were seeded with bone marrow cells in a porcine model. These constructs showed lowered risk of short-term (2 weeks) neo-intimal formation and thrombosis than grafts pre-clotted with whole blood; however, 3-month implantation resulted in substantial intimal hyperplasia, possibly due to the multi-potency of bone marrow cells (Cardon et al. 2000). Hasegava et al. (2007) implanted $2 \mathrm{~mm}$ thrombin-free fibrin-coated knitted polyester vascular grafts in carotid arteries in a rabbit model. Reduced platelet deposition and infiltration of immune cells, decreased expression of inflammatory markers, and improved fibrinolytic balance were observed when autologous fibrin was used rather than when fibrin of xenologous origin was used. In addition, spontaneous endothelialization was promoted (Hasegawa et al. 2007).

Fibrin glue has previously been used as a support for endothelialization in arterial prosthetic grafts, both experimentally (Fernandez et al. 2007) and in human trials, and it has been clearly shown that these conduits have better clinical performance (Meinhart et al. 2001, Deutsch et al. 2009); however, the underlying bypass graft material was ePTFE in most cases. A further exceptional contribution of our study is that we have adopted the approach of coating fibrin gel or fibrin/fibronectin assemblies onto clinically-used PET/Co bypass grafts. These types of vascular prostheses have been clinically implanted for decades; however, the lack of an endothelial lining in human often results in thrombotic events with serious health complications. Our results are clinically relevant with potential direct clinical application, because we used endothelial cells derived from patients with cardiovascular disease, and our experimental coating of the prosthesis resulted in excellent shear stress resistance of the seeded cells.

\section{Conclusion}

Human primary endothelial cells can sufficiently colonize a bare commercial knitted PET/Co vascular prosthesis in a serum-containing medium; however, significant cell detachment occurs after flow is applied. Coating the inner surface with laminin improves the cellular adhesion, but the shear stress resistance remains poor. Conversely, the resistance of the adhering cells to dynamic flow conditions mimicking the blood flow is significantly enhanced when the cells are plated on prostheses modified by a fibrin network or by fibrin/ fibronectin assemblies. These types of modifications may be suitable for the purposes of tissue engineering of vascular grafts.

\section{Conflict of Interest}

There is no conflict of interest.

\section{Acknowledgements}

Supported by the Ministry of Education, Youth and Sports of the Czech Republic (Barrande 2005-06-036-1 and grant No. EE2.3.30.0029), by the Grant Agency of the Czech Republic (grant No. P108/11/1857), by the Grant Agency of the Ministry of Health of the Czech Republic (project No NT11270-4/2010) and by the 
BIOCEV CZ.1.05/1.1.00/02.0109. We also thank Dr. Vera Lisá and Mrs. Ivana Zajanová for their excellent technical assistance in cell culturing and immunocytochemical staining, and Dr. Lucie Kubínová for helping with the confocal microscopy. We thank
Dr. Elzbieta Pamula, D.Sc. (AGH University of Science and Technology, Krakow, Poland) for providing the SEM picture of the vascular prosthesis. Mr. Robin Healey is gratefully acknowledged for the language revision of the manuscript.

\section{References}

ABDESSALEM SB, CHAKFE N, LE MAGNEN JF, BEAUFIGEAU M, ADOLPHE D, GENY B, AKESBI S, RIEPE G, KRETZ JG, DURAND B: Influence of crimping textile polyester vascular prostheses on the fluid flow kinetics. Eur J Vasc Endovasc Surg 18: 375-380, 1999.

BACAKOVA L, FILOVA E, PARIZEK M, RUML T, SVORCIK V: Modulation of cell adhesion, proliferation and differentiation on materials designed for body implants. Biotechnol Adv 29: 739-767, 2011.

BAITELLA-EBERLE G, LACHAT M, MÜLLER-GLAUSER W, NEUDECKER A, VON SEGESSER LK, TURINA M: Effect of hemodynamic conditions and prosthesis structure on endothelialization of clinical and experimental small lumen vascular prostheses (in German). Helv Chir Acta 57: 659-663, 1991.

BALAZ P, ROKOSNY S, KOZNAR B, ADAMEC M: Combined infrainguinal reconstruction and infrapopliteal intraluminal angioplasty for limb salvage in critical limb ischemia. Interact Cardiovasc Thorac Surg 9: 191-194, 2009.

BÉRARD X, REMY-ZOLGHADRI M, BOURGET C, TURNER N, BAREILLE R, DACULSI R, BORDENAVE L: Capability of human umbilical cord blood progenitor-derived endothelial cells to form an efficient lining on a polyester vascular graft in vitro. Acta Biomater 5: 1147-1157, 2009.

BORDENAVE L, MENU P, BAQUEY C: Developments towards tissue-engineered, small-diameter arterial substitutes. Expert Rev Med Devices 5: 337-347, 2008.

CARDON A, CHAKFÉ N, THAVEAU F, GAGNON E, HARTUNG O, AILLET S, KERDILES Y, DION YM, KRETZ JG, DOILLON CJ: Sealing of polyester prostheses with autologous fibrin glue and bone marrow. Ann Vasc Surg 14: 543-552, 2000.

CHAKFÉ N, BIZONNE SC, BEAUFIGEAU M, URBAN E, CARDON A, DOILLON C, LE MAGNEN JF, DURAND B, KRETZ JG: Impregnated polyester arterial prostheses: performance and prospects. Ann Vasc Surg 13: 509-523, 1999.

CHLUPÁC J, FILOVÁ E, BACÁKOVÁ L: Blood vessel replacement: 50 years of development and tissue engineering paradigms in vascular surgery. Physiol Res 58 (Suppl 2): 119-139, 2009.

DEUTSCH M, MEINHART J, ZILLA P, HOWANIETZ N, GORLITZER M, FROESCHL A, STUEMPFLEN A, BEZUIDENHOUT D, GRABENWOEGER M: Long-term experience in autologous in vitro endothelialization of infrainguinal ePTFE grafts. J Vasc Surg 49: 352-362, 2009.

FERNANDEZ P, BAREILLE R, CONRAD V, MIDY D, BORDENAVE L: Evaluation of an in vitro endothelialized vascular graft under pulsatile shear stress with a novel radiolabeling procedure. Biomaterials 22: 649-658, 2001.

FERNANDEZ P, BOURGET C, BAREILLE R, DACULSI R, BORDENAVE L: Gene response in endothelial cells cultured on engineered surfaces is regulated by shear stress. Tissue Eng 13: 1607-1614, 2007.

FEUGIER P, BLACK RA, HUNT JA, HOW TV: Attachment, morphology and adherence of human endothelial cells to vascular prosthesis materials under the action of shear stress. Biomaterials 26: 1457-1466, 2005.

FILOVÁ E, BRYNDA E, RIEDEL T, BACÁKOVÁ L, CHLUPÁC J, LISÁ V, HOUSKA M, DYR JE: Vascular endothelial cells on two-and three-dimensional fibrin assemblies for biomaterial coatings. $J$ Biomed Mater Res A 90: 55-69, 2009.

FILOVÁ E, BRYNDA E, RIEDEL T, CHLUPÁČ J, VANDROVCOVÁ M, SVINDRYCH Z, LISÁ V, HOUSKA M, PIRK J, BAČÁKOVÁ L: Improved adhesion and differentiation of endothelial cells on surface-attached fibrin structures containing extracellular matrix proteins. J Biomed Mater Res A 102: 698-712, 2014. 
GOUREVITCH D, JONES CE, CROCKER J, GOLDMAN M: Endothelial cell adhesion to vascular prosthetic surfaces. Biomaterials 9: 97-100, 1988.

HAJJAJI R, ABDESSALEM SB, GANGHOFFER JF: The influence of textile vascular prosthesis crimping on graft longitudinal elasticity and flexibility. J Mech Behav Biomed Mater 16: 73-80, 2012.

HASEGAWA T, OKADA K, TAKANO Y, HIRAISHI Y, OKITA Y: Autologous fibrin-coated small-caliber vascular prostheses improve antithrombogenicity by reducing immunologic response. J Thorac Cardiovasc Surg 133: 1268-1276, 2007.

HYNES RO: Cell-matrix adhesion in vascular development. J Thromb Haemost 5 (Suppl 1): 32-40, 2007.

JALALI S, DEL POZO MA, CHEN K, MIAO H, LI Y, SCHWARTZ MA, SHYY JY, CHIEN S: Integrin-mediated mechanotransduction requires its dynamic interaction with specific extracellular matrix (ECM) ligands. Proc Natl Acad Sci USA 98: 1042-1046, 2001.

JONAS RA, SCHOEN FJ, ZIEMER G, BRITTON L, CASTANEDA AR: Biological sealants and knitted Dacron conduits: comparison of collagen and fibrin glue pretreatments in circulatory models. Ann Thorac Surg 44: 283-290, 1987.

KACHLÍK D, STINGL J, SOSNA B, STRAKA Z, LAMETSCHWANDTNER A, MINNICH B, FÁRA P: Morphological features of vasa vasorum in pathologically changed human great saphenous vein and its tributaries. Vasa 37: 127-136, 2008.

KANNAN RY, SALACINSKI HJ, BUTLER PE, HAMILTON G, SEIFALIAN AM: Current status of prosthetic bypass grafts: a review. J Biomed Mater Res B Appl Biomater 74: 570-581, 2005.

KATSUMI A, ORR AW, TZIMA E, SCHWARTZ MA: Integrins in mechanotransduction. J Biol Chem 279: 1200112004, 2004.

KJAERGARD HK, WEIS-FOGH US: Autologous fibrin glue for sealing vascular prostheses of high porosity. Cardiovasc Surg 2: 45-47, 1994.

KONFRŠT J, LIEPSCH D, WEIGAND C: Experimental study of pulsatile flow in elastic model of PETP vascular grafts. Proceedings of the $3^{\text {rd }}$ International Symposium of Biofluid Mechanics, Munich, Germany, Abstract book: 582, 1994.

KONFRŠT J: Mechanical and hydrodynamical properties of arterial grafts. PhD Thesis, Czech Technical University, Faculty of Mechanical Engineering, Prague, Czech Republic, 2005.

MATIA I, JANOUSEK L, MARADA T, ADAMEC M: Cold-stored venous allografts in the treatment of critical limb ischaemia. Eur J Vasc Endovasc Surg 34: 424-431, 2007.

MEINHART JG, DEUTSCH M, FISCHLEIN T, HOWANIETZ N, FRÖSCHL A, ZILLA P: Clinical autologous in vitro endothelialization of 153 infrainguinal ePTFE grafts. Ann Thorac Surg 71 (5 Suppl): S327-S331, 2001.

ORTENWALL P, WADENVIK H, KUTTI J, RISBERG B: Endothelial cell seeding reduces thrombogenicity of Dacron grafts in humans. J Vasc Surg 11: 403-410, 1990.

PASQUINELLI G, FREYRIE A, PREDA P, CURTI T, D’ADDATO M, LASCHI R: Healing of prosthetic arterial grafts. Scanning Microsc 4: 351-362, 1990.

PRONK A, HOYNCK VAN PAPENDRECHT AA, LEGUIT P, VERBRUGH HA, VERKOOYEN RP, VAN VROONHOVEN TJ: Mesothelial cell adherence to vascular prostheses and their subsequent growth in vitro. Cell Transplant 3: 41-48, 1994.

PUNCHARD MA, STENSON-COX C, O'CEARBHAILL ED, LYONS E, GUNDY S, MURPHY L, PANDIT A, MCHUGH PE, BARRON V: Endothelial cell response to biomechanical forces under simulated vascular loading conditions. J Biomech 40: 3146-3154, 2007.

RÉMY M, BAREILLE R, RERAT V, BOURGET C, MARCHAND-BRYNAERT J, BORDENAVE L: Polyethylene terephthalate membrane grafted with peptidomimetics: endothelial cell compatibility and retention under shear stress. J Biomater Sci Polym Ed 24: 269-286, 2013.

RÉMY-ZOLGHADRI M, LAGANIÈRE J, OLIGNY JF, GERMAIN L, AUGER FA: Endothelium properties of a tissue-engineered blood vessel for small-diameter vascular reconstruction. J Vasc Surg 39: 613-620, 2004.

RIEDEL T, BRYNDA E, DYR JE, HOUSKA M: Controlled preparation of thin fibrin films immobilized at solid surfaces. J Biomed Mater Res A 88: 437-447, 2009. 
ROLL S, MÜLLER-NORDHORN J, KEIL T, SCHOLZ H, EIDT D, GREINER W, WILLICH SN: Dacron vs. PTFE as bypass materials in peripheral vascular surgery - systematic review and meta-analysis. BMC Surg 19: 8-22, 2008.

SALACINSKI HJ, TIWARI A, HAMILTON G, SEIFALIAN AM: Cellular engineering of vascular bypass grafts: role of chemical coatings for enhancing endothelial cell attachment. Med Biol Eng Comput 39: 609-618, 2001.

SARKAR S, SALACINSKI HJ, HAMILTON G, SEIFALIAN AM: The mechanical properties of infrainguinal vascular bypass grafts: their role in influencing patency. Eur J Vasc Endovasc Surg 31: 627-636, 2006.

SEEGER JM, KLINGMAN N: Improved in vivo endothelialization of prosthetic grafts by surface modification with fibronectin. J Vasc Surg 8: 476-482, 1988.

SENTISSI JM, RAMBERG K, O’DONNELL TF JR, CONNOLLY RJ, CALLOW AD: The effect of flow on vascular endothelial cells grown in tissue culture on polytetrafluoroethylene grafts. Surgery 99: 337-343, 1986.

SREEREKHA PR, KRISHNAN LK: Cultivation of endothelial progenitor cells on fibrin matrix and layering on dacron/polytetrafluoroethylene vascular grafts. Artif Organs 30: 242-249, 2006.

TAKADA Y, YE X, SIMON S: The integrins. Genome Biol 8: 215, 2007.

TUNSTALL A, EBERHART RC, PRAGER MD: Endothelial cells on Dacron vascular prostheses: adherence, growth, and susceptibility to neutrophils. J Biomed Mater Res 29: 1193-1199, 1995.

VARA DS, SALACINSKI HJ, KANNAN RY, BORDENAVE L, HAMILTON G, SEIFALIAN AM: Cardiovascular tissue engineering: state of the art. Pathol Biol (Paris) 53: 599-612, 2005.

VARGA M, MATIA I, LODEREROVA A, ADAMEC M: The minimal dose of FK506 is sufficient to facilitate the arterialisation of venous allografts in rats. European Surgery 45: 8-14, 2013.

VOHRA R, THOMSON GJ, CARR HM, SHARMA H, WALKER MG: The response of rapidly formed adult human endothelial-cell monolayers to shear stress of flow: a comparison of fibronectin-coated Teflon and gelatinimpregnated Dacron grafts. Surgery 111: 210-220, 1992.

WILLIAMS SK, KLEINERT LB, PATULA-STEINBRENNER V: Accelerated neovascularization and endothelialization of vascular grafts promoted by covalently bound laminin type 1. J Biomed Mater Res A 99 : 67-73, 2011.

WONG CS, SGARIOTO M, OWIDA AA, YANG W, ROSENFELDT FL, MORSI YS: Polyethyleneterephthalate provides superior retention of endothelial cells during shear stress compared to polytetrafluoroethylene and pericardium. Heart Lung Circ 15: 371-377, 2006.

ZILLA P, BEZUIDENHOUT D, HUMAN P: Prosthetic vascular grafts: wrong models, wrong questions and no healing. Biomaterials 28: 5009-5027, 2007. 